RESEARCH ARTICLE

\title{
The Institute of Archaeology Field Course at Downley Park, Singleton, West Sussex, UK. Multi Period Excavations Around the Hunting Lodge of the Earls of Arundel
}

\author{
Mark Roberts
}

This paper details and considers the results of excavations and research at Downley between 2015 and 2018. The primary aim of the project was to locate and prove the site of a late medieval - Tudor period hunting lodge that was mentioned in extant and archival literature but for which no physical trace existed. Four years of excavation, after an initial test pit survey, have revealed Tudor demolition debris; sub-Chalk surface intrusive features; a stone built tower with associated undercrofts; and additionally, evidence for Iron Age and Roman occupation within and without the curtilage of the lodge. The excavation and research will continue into 2019.

\section{The Institute's Field Course}

The Institute's field course runs from May into July each year and is attended by all the first year undergraduate students as part of their seventy day funded fieldwork requirement. They are joined each year by Graduate Diploma, Affiliate and post-Graduate students, who wish to build up, or begin their fieldwork portfolios. The field course is an integral part of the Institute's taught module "Field Methods and Techniques", where the Downley Project is woven into the teaching in terms of the specific application of procedures and practice, and also as an introduction to the design and execution of research. The linking of these strands creates a connected curriculum, which is driven by

Institute of Archaeology, UCL, London, WC1H OPY, United Kingdom, GB

mark.roberts@ucl.ac.uk research-led teaching. All the students are required to keep an assessed notebook diary of their experience and the teaching on the course, which in turn lays the foundation for the similar recording of their following fifty five days of fieldwork. The record culminates in the completion of two reports, on two separate placements, at the beginning of the final year. As reported earlier (Roberts 2014) the field course also trains between five and seven undergraduates in each year as field and post-excavation supervisors in an intensive eight week session: additionally, three students - two PhD candidates and a third year undergraduate, have taken on the role of Assistant Director.

One of the key research aims of the project is to locate and excavate the hunting lodge at Downley, which was a centre for the administration of the Honor of Arundel and other of the earls' estates in the $16^{\text {th }}$ century, 
as well as examining the surrounding earlier archaeological features, which are an integral part of a highly organised agrarian landscape from the Middle Bronze Age into the Roman Period. More broadly, therefore, the project considers Downley as part of a wider archaeological, historical, political and ecological landscape through time. In parallel with these research aims are a series of key learning objectives, these include the opportunity for students to learn a wide range of techniques and methods applicable in the discipline of field archaeology, and for supervisors and directors to be trained to a standard of competence that will allow them to work and thrive in the research and commercial archaeological sectors.

\section{Location and background}

Downley House is located within Cucumber Farm on the South Downs in south-east England, to the north-west of Singleton Village (NGR SU 486795 114375) (Figure 1), at altitudes between 140 and $135 \mathrm{~m}$ OD (Roberts 2014). The solid geology is the Seaford Chalk (Aldiss 2002), with significant but unmapped pockets of Clay-with-flints. The topography of the site area is consistent with that found across the downland dipslope, with highland areas and coombes (valleys), which drain southwards to the

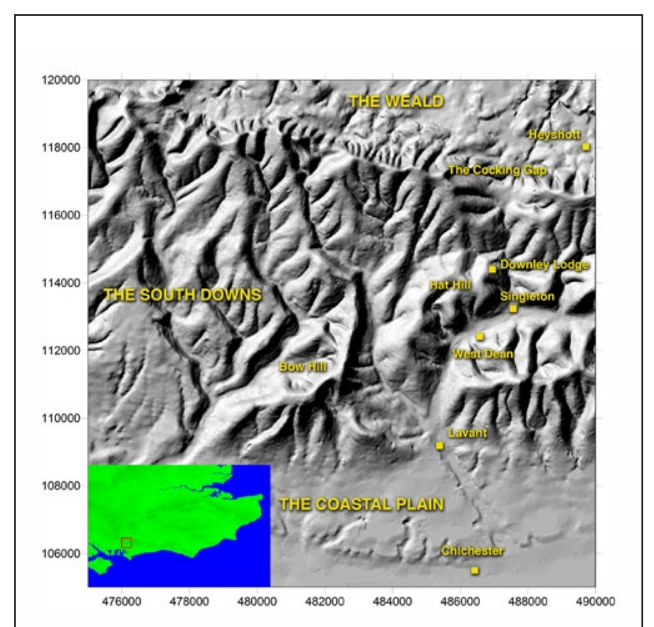

Figure 1: Location map and Digital Terrain Model of the area around Downley. [Contains OS height data].
Coastal Plain. This extant altitudinal topography is virtually unchanged since the end of the last glacial period 12,000 years ago, and the Chalk surface exhibits periglacial features in the form of stripes, on the north facing slopes.

The site of the lodge building is situated on a spur that runs north-east from Hat Hill, and was almost certainly chosen for the rare view afforded into the Weald by the Cocking Gap (Figure 1). The lodge sits within the Downley deer park, demarcated by a park pale consisting of an internal ditch and external bank, upon which the paling fencing would have been set. The park has a circumference of $6.622 \mathrm{~km}$ and an area of 261.7 ha (Figure 2). Today the area that comprises the park is part of the National Trust's Drovers' Estate, and marches with the Cowdray Estate to the north and the West Dean Estate to the south and west.

Deer parks were enclosed areas for the protection and exploitation of deer (Cantor and Hatherly 1979; Ellis 1885; Fletcher 2011; Mileson 2009), which were common features in Medieval and Tudor England and Wales. Within the Forest of Arundel during the 1500s there were seven parks and inside the whole Honor of Arundel at least sixteen, including one owned by the Archbishop of Canterbury and one owned by the Bishop of Chichester. The parks were a repository of animals protected from poaching, and the encroachment of assarts (creation of wastes and agricultural land) and agistment (grazing rights for revenue) in the forest, which provided venison for the owner for consumption and gift-giving. They were also a gene pool from which deer were moved and swapped for the purposes of breeding and replenishment. Apart from their quotidian existence, which also included grazing of domesticated animal and the production of timber and other crops; parks at the time of their occupation by house and hunting parties were areas of sanctuary where affairs of politics business 


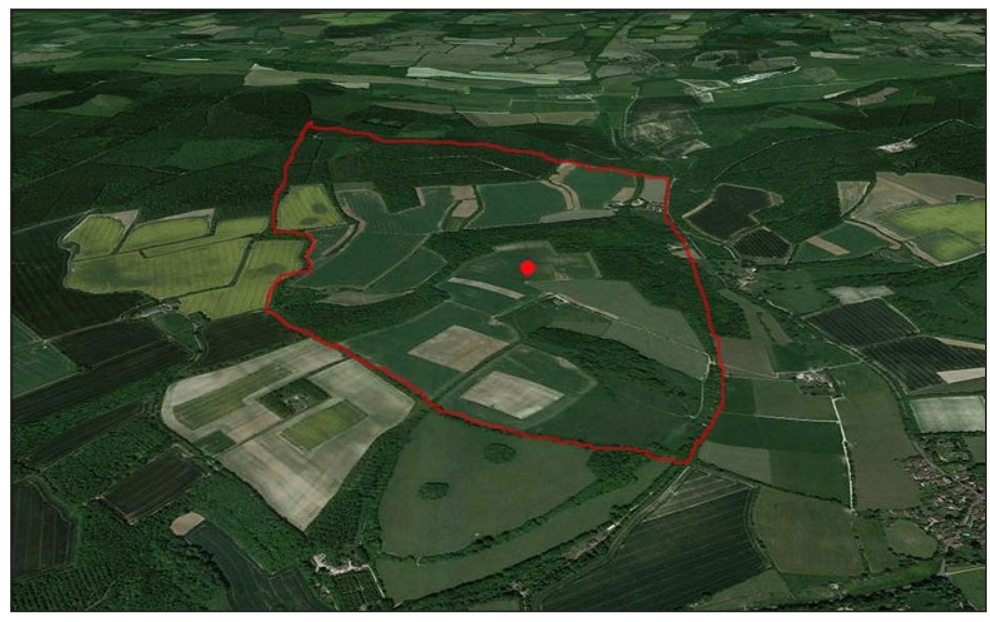

Figure 2: Oblique view of Downley Park looking NW. The house is located in the centre of the park, marked by the red dot. Park parameters are given in the text. [Underlay Google Earth].

and matchmaking were carried out amongst members of the nobility; perhaps under less scrutiny than in the outside world (Liddiard 2007).

\section{Excavation}

The area excavation has been almost entirely located within an area of set-aside, surrounded by arable fields, from the initial survey in 2014 up to excavation in 2018 (Figures 3 and 4) (Roberts 2014). Where excavation boundaries have exited the setaside an equivalent arable take back has been made on the northern and eastern edges of the area. The preliminary work involved the excavation of linear slit trenches, which then developed, based upon features and finds discovered, into larger area excavations that have run from 2015-2018.

Foundations associated with a section of the Tudor building were first revealed in 2016, they are visible in Figure 5 but represent only the tower part of the house as recorded in the Harris and Dawbis' (1570) inventory of the Honor of Arundel. The building is built upon and cut into the chalk bedrock to a depth in excess of $2.00 \mathrm{~m}$ in the northern section: three under-croft style rooms survive together with a mortar reinforced plinth that perhaps supported an external staircase.
The building fabric contained elements re-used from an older structure, as indicated by the presence of dressed Caen stone with chisel marks redolent of those employed in the late $14^{\text {th }}$ century. The demolition debris excavated is, with the exception of the dressed stone, from a Tudor building, which was originally thought to have been built upon earlier Medieval foundations but the complete absence of pottery and other pre-Tudor finds precludes this hypothesis. The tower building was largely constructed of Upper Greensand malmstone and dressed flint, with very little brick found in the demolition debris (Figure 6). The position of the main dwelling house remains unproven, although its most likely position is in the area surrounded on three sides by the 2015-2018 excavations (Figure 7).

Other pointers to the house's position, include a Tudor hedge ditch that almost certainly marks the inner curtilage of the house, this thin shallow linear feature is visible running NE and SE in Figures 4 and 5. Also within the hedge ditch, are a screened-off cess pit revealed in Trench 16 and an external partial cellar excavated in Trench 17 in 2015. The latter contained a wide range of Tudor domestic debris including imported saltglazed stoneware, bottle glass, glassware and carved bone beads. The hedge ditch at the 


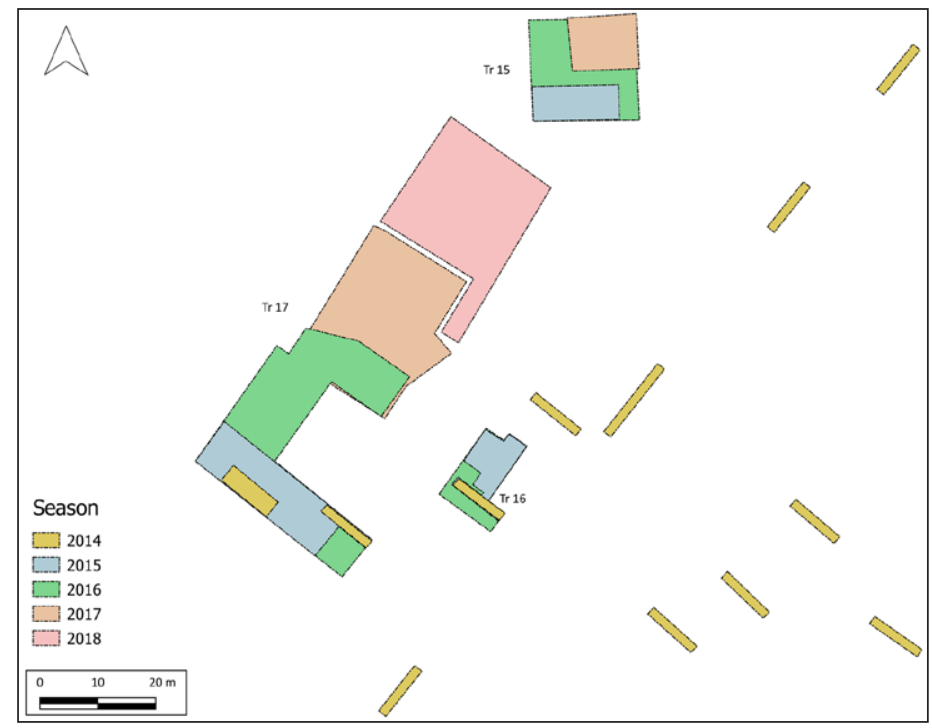

Figure 3: Plan showing all the excavation trenches and areas up to the end of 2018. [Rob Kaleta/Downley Project].

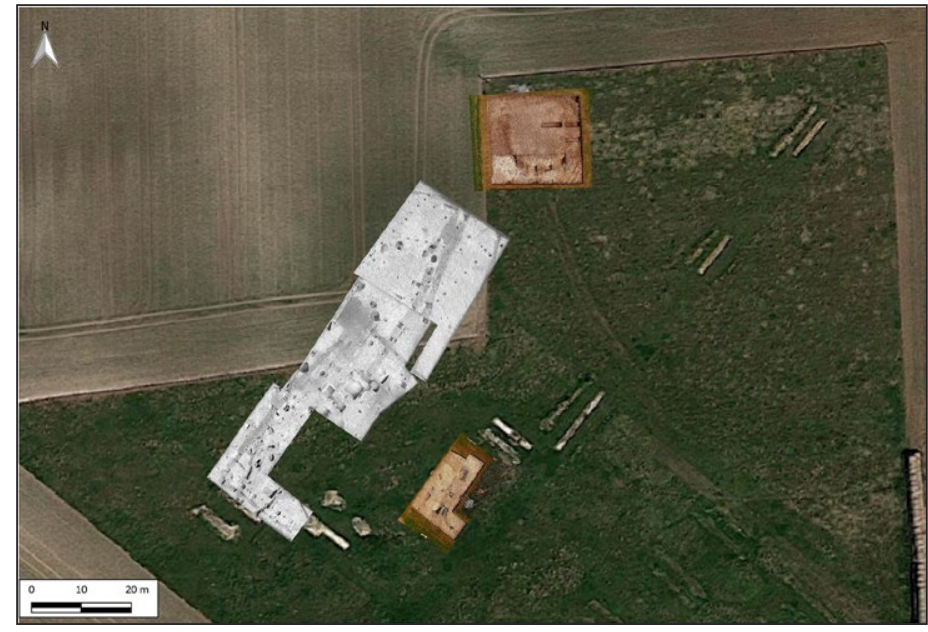

Figure 4: Aerial image, showing the position of the existing excavations 2015-18. [Base layer Google Earth. Rob Kaleta/Downley Project].

southern end of the site contains a substantial amount of domestic debris, mostly bone, nails and some pottery. Further to the north, and thus it is assumed further from the house, the ditch contains almost no domestic debris but material associated with the demolition of the house such as tile and brick fragments. The hedge ditch and Tudor postholes found in the 2018 excavation (Figure 7), suggest that the house sat in a planned garden that also encompassed the aforementioned tower. The excavated evidence demonstrates that the house employed high-status, expensive, construction materials such as brick and tile, alongside the Upper Greensand and dressed flint there is also evidence for the use of Sussex marble in decorative features such as fireplaces. Together, these suggest that the lodge was built in an essentially composite style from a wide range of materials, similar 


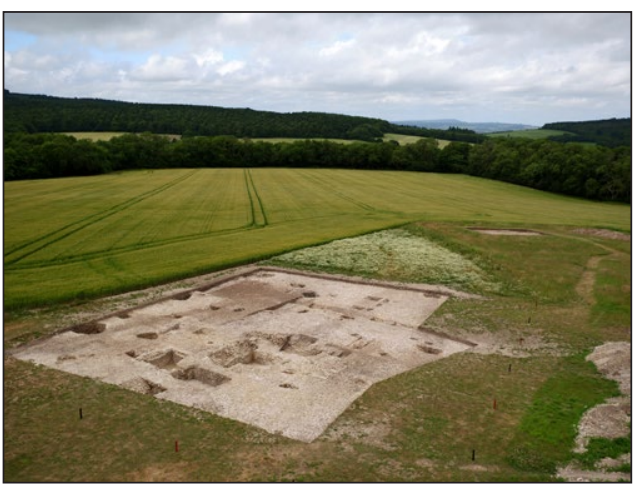

Figure 5: The excavation area looking north, at the end of 2017. Trench 17 in the foreground, with the under-crofts of the tower building visible at the southern end. Note the view through the Cocking Gap. (Pegs at $5 \mathrm{~m}$ separation). Photo: MBR.

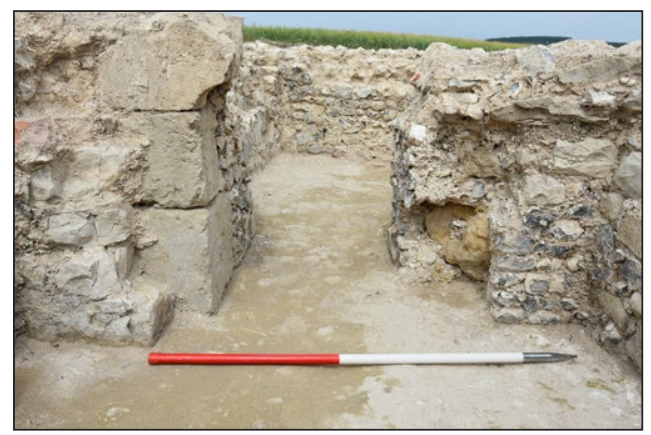

Figure 6: Detail of the construction showing dressed Caen stone, Upper Greensand wall-fill, and dressed flint internal facings. (Scale $0.5 \mathrm{~m}$ divisions). Photo: MBR.

to the Yeoman's House at Bignor but with a tiled roof (Figure 8).

Evidence for flooring is plentiful and includes high status, imported, glazed floor tiles, home-produced floor tiles and a range of flagstones from various Wealden lithologies. The work carried out to date clearly demonstrates that most of the constituent parts of the house and tower were taken off site after demolition and were almost certainly then used in the construction of other buildings in the area. The excavations illustrate that the house, tower and gardens are located within a complex of earlier archaeological features, including Iron Age and Roman ditches and pits (Figures $\mathbf{5}$ and 7). Excavation has revealed the problems that these features caused for the Tudor builders, and their response that took the form of increased foundation thicknesses, the construction of chalk block walls, and the partial digging-out of at least one Roman ditch. The largest Iron Age ditch runs West-East through the site and is entirely truncated by the tower building (Figure 9). Large and deep Iron Age pits are located both north and south of the ditch as revealed by the excavations from 2016-2018 (Figures 4 and 10). The pits often contain votive or closure deposits, such as animal skulls, polished exotic stones, an antler tine pendant, and a bone tablet with incised circles (Figure 11) (Cunliffe 2005).

No human bones, however, have yet been identified from either the features or the site in general (Booth and Madgwick 2016). The purpose of the pits is hard to elucidate as they all appear to have been deliberately backfilled, some from empty, others after an initial period of natural infill; in this regard they are similar to the main and subsidiary ditches which also exhibit evidence of deliberate backfill (Figure 9). The principal elements of non-natural backfill are very large natural flint clasts, which in many cases have been pounded into each other and the soil matrix, and burnt flint. Another surprising recovery from the pits are well-made roundnosed end scrapers, there is little doubt that these are contemporary with the backfill and might have, in conjunction with the burnt flint, related to the processing of animal hides. There is also a considerable quantity of pottery, with many decorated sherds, which upon initial examination dates to the Middle Iron Age (M. Seager-Thomas pers comm.). Iron Age querns, both saddle and round, have been found at site; an elongate pit partially excavated in 2018 contained nine pieces of broken quern, mostly of local sandstone from the Weald. The Iron Age finds indicate the presence of a domestic site, with evidence for industrial processes involving the boiling of quantities of water. At this stage 


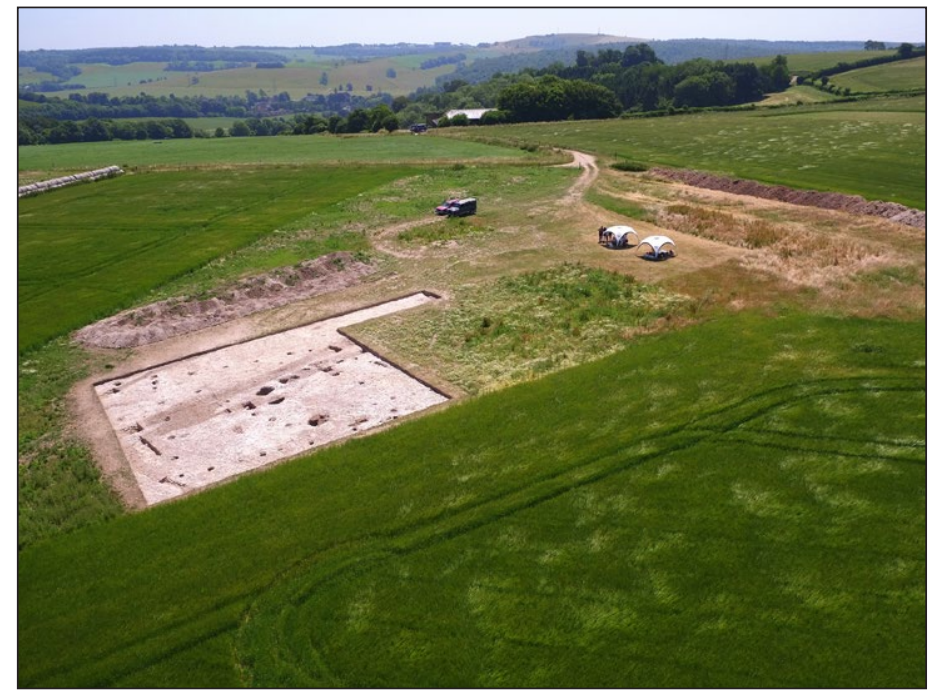

Figure 7: Looking SE across the site in 2018, towards the Trundle hill fort on the horizon. The mown area under the tents is the most likely location of the main house and will be excavated in 2019. Photo: MBR.

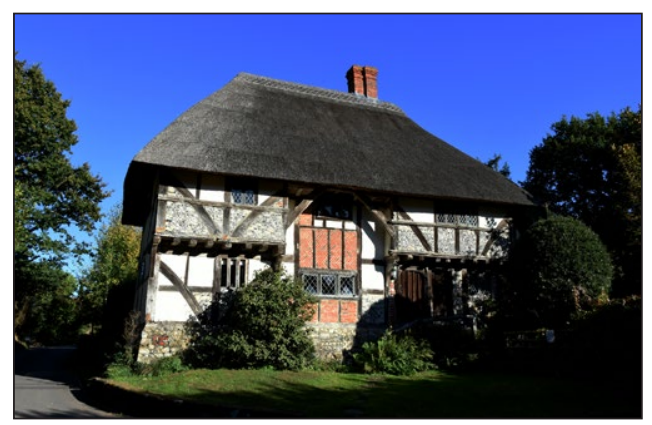

Figure 8: The late C.15th Yeoman's House at Bignor, $11.5 \mathrm{~km}$ to the east of Downley (Figure 15). Photo: MBR.

of the project the pits are interpreted, at a functional level, as abandoned grain storage features.

In the main part of the site at Trenches 16 and 17 Roman ditches were uncovered running N-S and W-E, they are most likely to be associated with agricultural activity as the pottery assemblage they contain consists of similar sized sherds of abraded pottery that is usually indicative of manuring and ploughing. However, to the north in Trench 15 and in the northernmost part of Trench 17, a Roman ploughsoil and subsoil have been

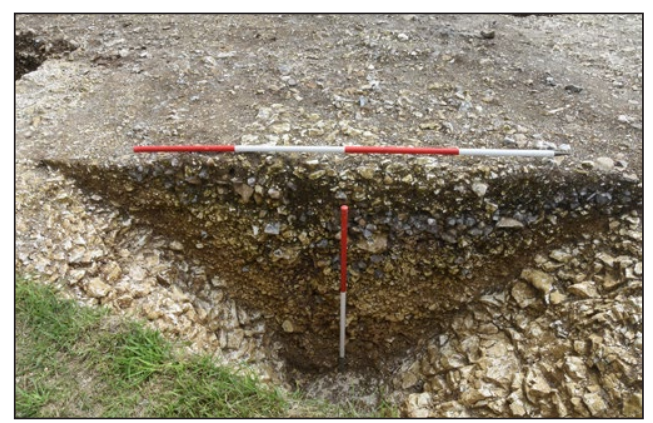

Figure 9: Section through the IA ditch in Tr17, looking east, note the large amount of burnt flint tipped into the ditch from the south. (Scales $0.5 \mathrm{~m}$ divisions). Photo: MBR.

observed and excavated: they underlie the modern ploughsoil and surviving patches of Tudor demolition debris, and increase in depth to the north as the ground falls away down the spur of Hat Hill into the Wellhanger Valley/Dog Kennel Bottom (Roberts 2014; Figures 3 and 4). In places the combined Roman soil depth is over $0.5 \mathrm{~m}$, with the pottery in the basal part being of larger size and unabraded. Much of the assemblage comprises local wares from nearby Rowlands Castle and Alice Holt kilns alongside finer, 
imported slip wares and occasional sherds of Samian. The subsoil has been shown to overlie other Roman features such as ditches and pits (Figure 12). The Roman layers contain food debris, pottery, glass and coins that range from the second to fourth century AD.

\section{Further documentary evidence relating to Downley}

The Arundel Archives contain very important documentary data that relate to the Honor of Arundel, the Forest of Arundel and the parks contained therein, including Downley, from the $13^{\text {th }}$ to the $17^{\text {th }}$ centuries. Material from the archive is currently being studied by the author outside of the summer excavation season. The earliest mention of Downley (Le Dunle) is from an Inquisition held at Singleton that dates to 1272 , during the reign of Henry III (Heneage 1580; PRO 1916).

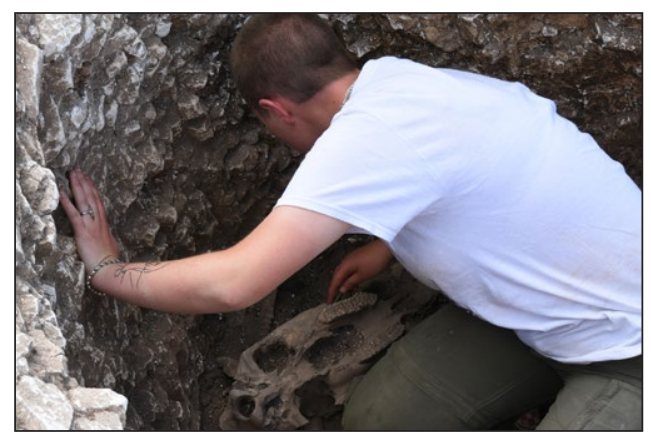

Figure 10: First year student Caragh MurphyCollinson in one of the Iron Age pits with an inverted horse cranium. Photo: MBR.
The document describes the granting of permission to cut down beech trees for paling the park. Whether this event represented the initial imparkment or the replacement of an existing pale remains to be elucidated.

There are detailed inventories of the Fitzalan estates in the archive that include a record of the parks, boundaries of the Forest of Arundel, and income and boonworks from the various manors in Sussex and beyond. They were compiled in the $14^{\text {th }}$ and very early $15^{\text {th }}$ centuries (Clough 1969), but also draw on older documents and records such as that contained in the Testa de Nevill (PRO 1920, 1923). State records in the form of Letters Patent, Closed Rolls, Hundred Rolls, Fine Rolls, Calendars

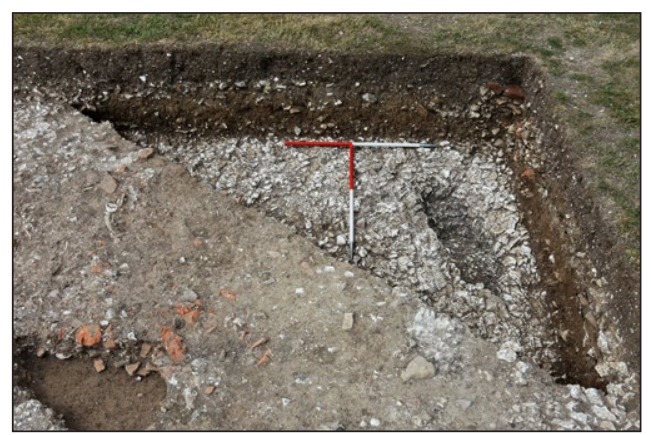

Figure 12: The NE corner of Trench 15, showing the Tudor rubble layer overlying the Roman ploughsoil (foreground and section). The base of an oval pit is visible, cut into the chalk. (Scales $0.5 \mathrm{~m}$ divisions). Photo: MBR.

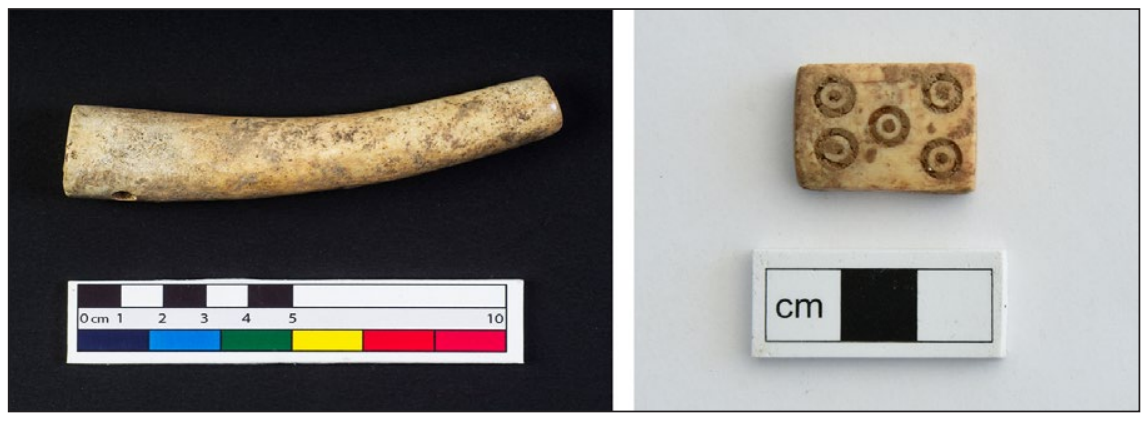

Figure 11: Carved antler tine and polished bone fragment with incised circles, both from Iron Age pits at the site. [Left hand image Conservation Department, Institute of Archaeology, UCL]. Photo: MBR. 
of Inquisition Post Mortem, together with books such as Cockayne's Complete Peerage (1910) and Turner's Select Pleas of the Forest (1901), include a wealth of detail on the matters affecting and relating to the earls of Arundel, the Honor, and the Forest. These records and works contain detailed information on subjects of interest such as: the reversion of the estate to the crown during periods when the earl was attainted or the heir was in his nonage, guardians of the Wards of the Honor, details on manors and other resources in dower, grants relating to hunting and imparkment, poaching and legal disputes. Just prior to this year's excavation further documentary evidence was found by the Arundel Archivist Heather Warne and part-transcribed by MBR and students on the Field Methods course. It comprises two competi of accounts from the reigns of Henry VII and VIII (Anon 1508-09, 1540-41). These documents refer to fees and wages paid to estate workers, including wardens, foresters, rangers and fencers (pale maintenance). Most interestingly, sewn into the draft compotus roll was a set of signed and sealed letters written (in English) by
Thomas Fitzalan Earl of Arundel (14501524), approving and authorising fees and wages paid to workers in the Honor, and which ties up with the earlier account roll (Figures 13 and 14).

A later document found in the archives is a custumal relating to the villagers of Singleton and Charlton dating from 1580 that confirms Downley as one of the three principal dwellings of the earls of Arundel/dukes of Norfolk in Sussex alongside Arundel and Stansted (Anon 1580). It is however surprising that Downley figures so prominently in the custumal because the survey of the Honor of Arundel, prior to the death of Henry Fitzalan in 1579, mentions that the buildings were in a state of disrepair (Harris and Dawbis 1570). It might have been that the earl or his son-in-law Sir John Lumley had the building renovated in order to rent it to the Lewkenor family who resided there in the late $\mathrm{C} 16^{\text {th }}$ and possibly early $\mathrm{C} 17^{\text {th }}$, in addition to their property at Stansted and latterly West Dean. It should be noted when considering the abandonment and demolition of the house at Downley that only two pieces of clay pipe stem have been recovered from the modern

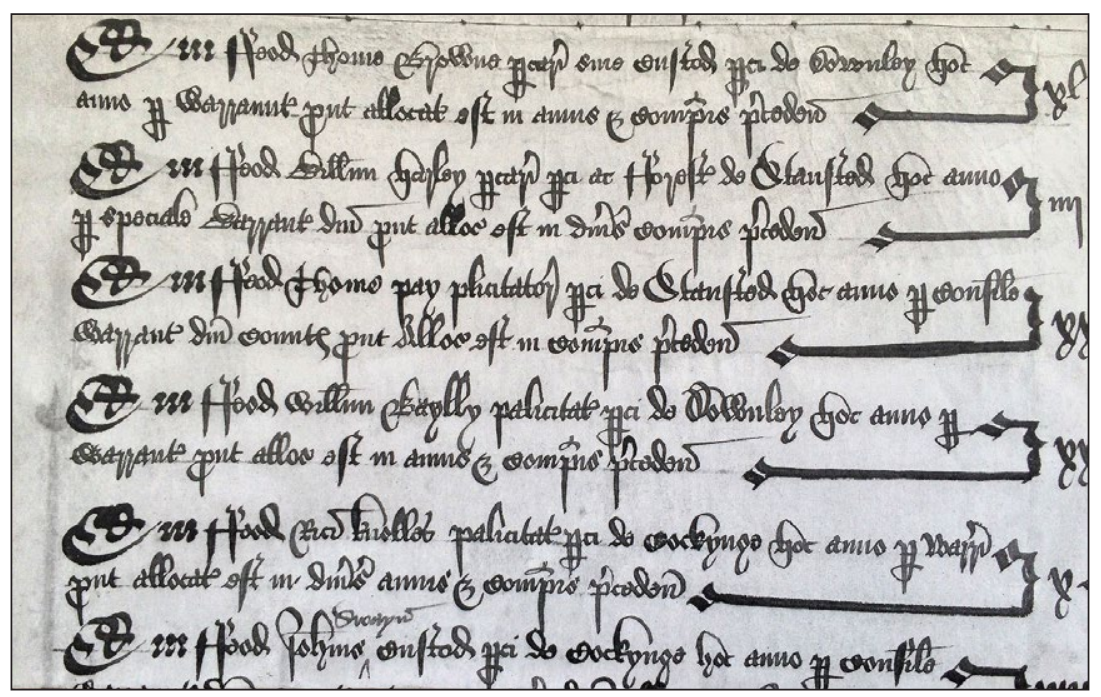

Figure 13: Compotus for the Honour of Arundel compiled for Thomas earl of Arundel in the early Sixteenth Century. Note the mention of William Baylly fencer in the park of Downley and at the top Thomas Browne who was the warden of the park. Photo: MBR (used with permission of His Grace the Duke of Norfolk). 


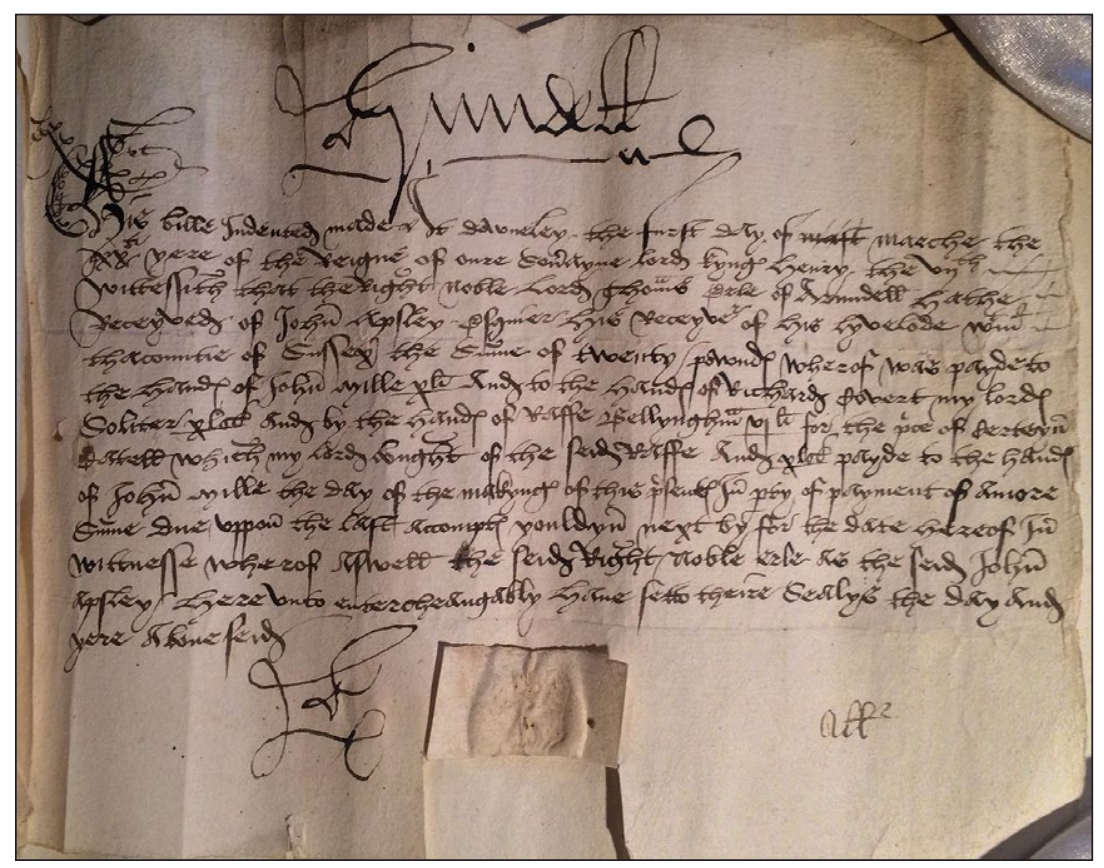

Figure 14: Letter written, signed and sealed at Downley by Thomas Fitzalan on the $1^{\text {st }}$ March in the $20^{\text {th }}$ year of Henry VII (1506). Photo: MBR (used with permission of His Grace the Duke of Norfolk).

ploughsoil and none from any features or preserved layers of demolition debris. This absence of evidence does, in this instance, provide a reasonable terminus ante quem for the site, to the early $\mathrm{C} 17^{\text {th }}$, as the take up of the clay pipe as the preferred medium for smoking tobacco accelerated after 1620 (Oswald 1961).

\section{Discussion}

The site at Downley contains evidence for multi-period occupation of this area of the Downs for almost three millennia. The nature of the evidence in terms of its preservation, rarity, and ability to answer period specific research questions means that the site is of national importance, further excavation and historical research might elevate this status to international importance. Correspondence from Downley confirms that affairs of state, which extended to all parts of Europe, were conducted from the house throughout the late $15^{\text {th }}$ and $16^{\text {th }}$ centuries, with letters going to and coming from the
King, Thomas Cromwell, Cardinal Wolsey and others. The letters combined with the fact that antepenultimate and penultimate earls died at Downley, along with finds such as treasury counters, seals and bullion weights, strongly suggests that the Fitzalan estate was run from Downley from the late fifteenth century up until at least 1544; accordingly, now these circumstance are known they may now be investigated and studied in the light of the political and religious milieu prevailing during this time period.

The Downley Park fieldwork has become part of a wider project looking at the workings of the Forest of Arundel from the Conquest until the retrenchment of the estate back to its present boundaries (Figure 15) (Langton and Jones 2010). This large-scale project will combine the historical analysis with landscape survey and archaeology to examine the workings of this comital forest through time (Bazeley 1921; Nelson 1717). It will study aspects such as the interplay of forest and common law, the revenue of the forest, 
the interaction with other landowners in the area of the forest, such as the Bishop of Chichester (Blauw 1850; Peckham 1942), the parks and woods of the forest and their administration, the effects of imparkment, and finally the break up and sale of the western part of the forest.

The project has also expanded its original brief because of the discovery of the Iron Age and Roman finds made during the excavations. Whilst the Roman material, perhaps relating to a nearby farm or small villa, is not uncommon on the Downs in this area, the Iron Age activity is more of a rarity. The sparse nature of Iron Age sites is somewhat incongruous when considered in the light of the enigmatic large lynchet-like structures found around Hat Hill and elsewhere in the West Dean area (Sillar, Sommer and Davis 2008), together with the extensive field systems of the downland dipslope that appear to have been at their apogee during the Iron Age (Busby 2016; Carpenter et al. 2016; Hooper 2016). These features suggest a much more developed and continuous Iron Age presence on the Downs, an interpretation that has been questioned by archaeologists as an ever growing amount of evidence points to greater occupation of the Coastal Plain during this period (Bedwin 1978; Fitzpatrick, Powell and Allen 2008; James Kenny pers. com; Walker 2018). Apart from small scale settlements such as Carne's Seat at Goodwood (Holgate 1986), Rummages Barn (Kenny 1985); agricultural features such as the stockade at Goosehill Camp, Bow Hill (Boyden 1956; Roberts in prep.); and the hillfort at the Trundle (Curwen 1931), there is little visible infrastructure to support the large scale agricultural enterprise that was taking place over an area in excess of 25,000 hectares. It might be that the activities and settlement at sites like Downley are the first indication of that infrastructure.

The Downley Project has proven to be an extremely valuable teaching tool for students at the Institute at many stages of their study, it has also forged and continued vital links with other partners such as the West Dean Estate, the Goodwood Estate, the Arundel Estate, the National Trust, the Weald and Downland Museum, the University of Chichester, and the South Downs National Park Authority. The students are involved in all stages of the project, including the project liaison with the bodies listed above. Their participation gives them an appreciation

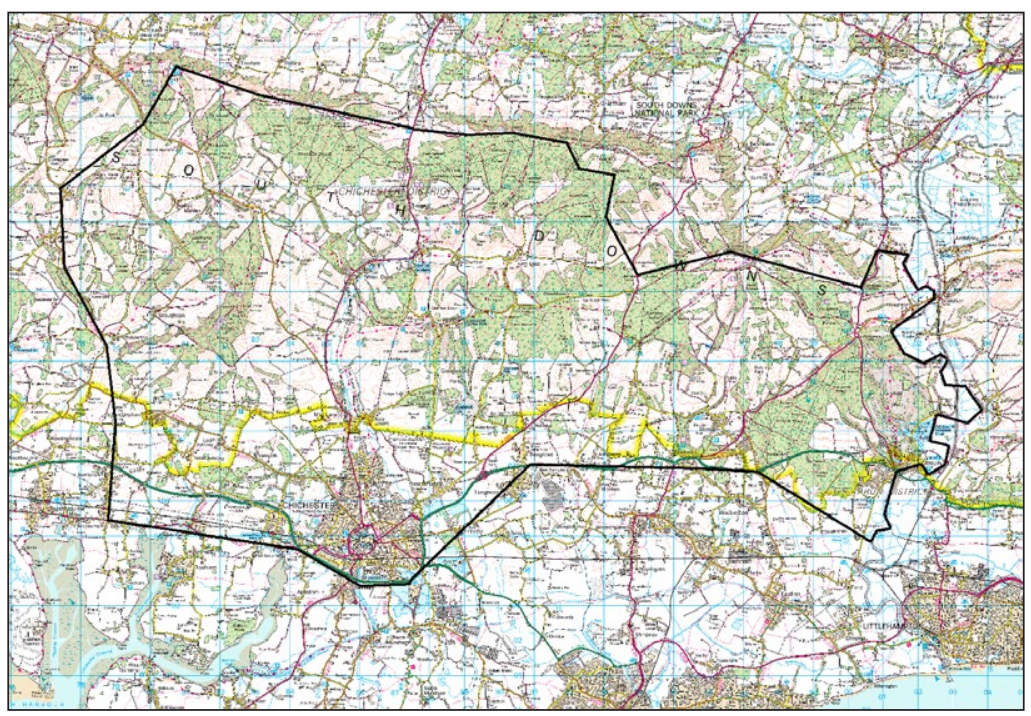

Figure 15: The bounds of the Forest of Arundel from Fitzalan Survey Book B (Clough 1969), drawn on an Ordnance Survey 1:50k basemap. [Base Image OS copyright]. 
of the transferrable skills required by, and developed within, the discipline, which they can later utilise in all forms of employment and further post-graduate study.

\section{Acknowledgements}

Thanks are due to many people for allowing this project to develop and flourish, not least among these are Lady Elizabeth Benson at Downley and James Kenny the Chichester District Archaeological Officer, without either of whom the project simply would not have got off the ground. Tom Dommett and the National Trust have been supporters and facilitators throughout the project, as have Alex Barron and Ian Graham at West Dean, and Richard Pailthorpe and Paul Rigg at the Weald and Downland Museum. On the ground David Penny the Farm Manager at Cucumber Farm has provided immeasurable help and advice, as has Darren Norris the Forestry manager at Goodwood. John Mills, the County Archaeologist at West Sussex County Council has been a staunch supporter and companion. I have received endless kindness and encouragement from the staff at the Arundel Archives and thank his Grace the Duke of Norfolk for permission to use images of the documents illustrated here. Finally, a big thank you to all the students who have passed through and helped at Downley, notably the supervisors and most especially Mariana Nabais, Rob Kaleta and Alec Walker who directed with me.

\section{Competing Interests}

The author has no competing interests to declare.

\section{References}

Aldiss, D T 2002 Geology of the Chichester and Bognor District. Sheet description of the British Geological Survey, 1(50).

Anon 1508-09 Compotus for the Honor of Arundel. Arundel Archives A235.

Anon 1540-41 Compotus for the Honor of Arundel. Arundel Archives A 247.
Anon 1580 Custumals for the villages of Singleton and Charlton. Arundel Archives MD 259.

Bazeley, M L 1921 The extent of the English Forest in the thirteenth century. Transactions of the Royal Historical Society, $4^{\text {th }}$ Series, 4: 140-172.

Bedwin, O 1978 Iron Age Sussex - the Downs and Coastal Plain. In: Drewett, $\mathrm{P}$ (ed.) Archaeology in Sussex to AD 1500. London: CBA. 41-51.

Blauw, W H 1850 Letters to Ralph de Nevill, Bishop of Chichester, 1222-1244, and Chancellor to King Henry III. Sussex Archaeological Collections, 3: 35-76.

Booth, T J and Madgwick, R 2016 New evidence for diverse secondary burial practices in Iron Age Britain: Journal of Archaeological Science, 67: 14-24. DOI: https:// doi.org/10.1016/j.jas.2016.01.010

Boyden, J 1956 Excavations at Goosehill Camp 1953-1955. Sussex Archaeological Collections, 94: 70-99.

Busby, P 2016 The "Secrets of the High Woods" Project East Dean Woods, West Sussex: Archaeological Excavation, CA Report 16372. Milton Keynes: Cotswold Archaeology.

Cantor, L M and Hatherly, J 1979 The Medieval Parks of England. Geography, 64(2): 71-85.

Carpenter, E, Small, F, Truscoe, K and Royall, C 2016 South Downs National Park: The High Woods from Above NMP. Swindon: Historic England.

Clough, M (ed.) 1969 Two Estate Surveys of the Fitzalan Earls of Arundel. Sussex Record Society Volume LXVII. Lewes: SRS.

Cockayne, G.E 1910 The Complete Peerage Volume 1. London: St. Catherine Press.

Cunliffe, B 2005 Iron Age Communities in Britain, 4th Edition. London: Routledge.

Curwen, E 1931 Excavations at the Trundle, second season 1930. Sussex Archaeological Collections, 72: 100-149.

Ellis, W S 1885 The parks and Forests of Sussex. Lewes: H. Wolff.

Fitzalan, T 1506 Estate correspondence letters. Arundel Archives (Unregistered). 
Fitzpatrick, A P, Powell, A B and Allen, M J 2008 Archaeological Excavations on the Route of the A27 Westhampnett Bypass West Sussex, 1992: Volume 1: Late Upper Palaeolithic-Anglo-Saxon. Salisbury: Wessex Archaeology Reports.

Fletcher, J 2011 Gardens of Earthly Delight: the History of Deer Parks. Oxford: Oxbow Books.

Harris, $\mathbf{R}$ and Dawbis, $\mathbf{J} 1570$ A survey of the Honor of Arundel. Arundel Castle Archives MD 535: Fo. 26v-27r.

Heneage T 1580 Transcription of an Inquisition held at Singleton in 1272. Arundel Archives MD 1231.

Holgate, R C 1986 Excavations at the Late Prehistoric and Romano-British enclosure complex at Carne's Seat, Goodwood, West Sussex, 1984. Sussex Archaeological Collections 124: 35-50.

Hooper, F 2016 Analysis of field systems revealed by LiDAR in Charlton Forest, West Sussex, UK. Unpublished dissertation (BSc), University College London.

Kenny, J 1985 Excavations at Rummages Barn, Binderton, West Sussex, 1983. Sussex Archaeological Collections, 123: 61-72.

Langton, J and Jones, G (eds) 2010 Forests and Chases of Medieval England and Wales c.1000-c.1500. Oxford: St John's College Research Centre.

Liddiard, R (ed.) 2007 The Medieval Park: new perspectives. Macclesfield: Windgather.

Mileson, S A 2009 Parks in Medieval England. Oxford: Oxford University Press.
DOI: https://doi.org/10.1093/acprof: oso/9780199565672.001.0001

Nelson, W 1717 Manwood's Treatise of the Forest Laws. London: J. Nutt.

Oswald, A 1961 The evolution and chronology of English clay tobacco pipes. Archaeological News Letter, 7(3): 55-62.

Peckham, W D (ed.) 1942 The Chartulary of the High Church of Chichester. Sussex Record Society Volume XLVI. Lewes: SRS.

Public Records Office 1916 Calendar of Inquisitions Miscellaneous (Chancery). C. Inq. Misc. File 17 (18.). London: HMSO.

Public Record Office 1920 Liber Feodorum: Testa de Nevill. London: HMSO.

Public Record Office 1923 Liber Feodorum: Testa de Nevill. London: HMSO.

Roberts, M B 2014 The Institute of Archaeology Field Course 2014: The Search for the Lost Hunting Lodge of the Earls of Arundel at Downley, Singleton, West Sussex, UK. Archaeology International, 17: 109-121. DOI: https://doi.org/10.5334/ ai. 1722

Sillar, B, Sommer, U and Davis, R 2008 West Dean 2008: Bronze Age Lynchets on Little Combes Hill. Archaeology International, 11: 54-57. DOI: https://doi. org/10.5334/ai.1115

Turner, G J 1901. Select Pleas of the Forest. Selden Society Volume XIII. London: Bernard Quaritch.

Walker, A 2018 An evaluation of the condition and significance of the site archives from excavations at Lavant Down, West Sussex. Unpublished dissertation (BSc), University College London.

How to cite this article: Roberts, M 2018 The Institute of Archaeology Field Course at Downley Park, Singleton, West Sussex, UK. Multi Period Excavations Around the Hunting Lodge of the Earls of Arundel. Archaeology International, 21 (1), pp. 141-152. DOl: https://doi.org/10.5334/ai-394

Submitted: 27 September 2018 Accepted: 27 September 2018 Published: 05 December 2018

Copyright: (c) 2018 The Author(s). This is an open-access article distributed under the terms of the Creative Commons Attribution 4.0 International License (CC-BY 4.0), which permits unrestricted use, distribution, and reproduction in any medium, provided the original author and source are credited. See http://creativecommons.org/licenses/by/4.0/. 